\title{
EFFECTIVENESS OF USING E-LEARNING FOR BUSINESS DISCIPLINES: THE CASE OF INTRODUCTORY MANAGEMENT COURSE
}

\author{
Hana Mohelská, Marcela Sokolová
}

\section{Introduction}

Systematic training of employees is a constantly repeated cycle that reflects both the specific requirements of training and development strategies, as well as the objectives of general organizational strategy. The main source of the training and development process efficiency is its systematic feature in relation to employees and to owners and customers. Systematic training consists of four basic stages [2]:

- identification of needs,

- planning and budgeting,

- implementation,

- evaluation of the process effectiveness and its projection to the next round; so it is a closed process based on continuous improvement.

Although it's a cycle of successive stages, each of them occurs in the system as a somewhat separate sub-process, which is independent of the other activities accelerated by organisational and institutional prerequisites for the development of employees. It means not only the existence of a group of employees and organisational units that participate in the provision of professional and organisational aspects of education, training programs and training facilities, but also creating conditions for continuous development that places less emphasis on formal training and emphasising human responsibility for self-education and self-development. Another source of acceleration is also the fact that in the process management system of training and development, the individual phases are successive, overlap and influence each other. Parts of the cycle are therefore both separate and complementary processes, which together provide a synergistic effect [2].
Education and development of employees in the traditional sense focus on the formation of working abilities of a person and that part of their personality, through which they create values in order to improve the work performance of individuals, to fulfil their individual goals within their working career and improve the performance of an organization as a whole. It serves as a permanent provision of skills that are needed in the organization for the performance of existing or future work.

Education is an organized institutionalized way of learning. Training should be systematic and it is limited - it has a beginning and an end. [14]

Learning is a more complex concept than education. It is a process of change that involves new knowledge and behaviour. Unlike education, learning takes place spontaneously. [14], [20]

Armstrong [2], [1] says that corporate training core goals are especially to increase the performance of permanent staff and development of skills, to be able to perform new tasks by the newly recruited staff as soon as possible and at minimal cost. He sees corporate education as an investment in people, which should return to the company. With the onset of the economic crisis in late 2008, many companies in the Czech Republic decided to cut down on expenses for employees whether they were labour costs, in which reduction led to redundancies or to reduce spending on the training of employees.

The purpose of education is to promote competitiveness and a greater flexibility of workers in a rapidly changing environment. Companies that have an established system of education, have more educated employees who are more productive and a better understanding 
of their work, and they are also able to adapt quickly to changes and new technology, which gives them a significant competitive advantage. [14], [20]

Results of the survey of the Czech Statistical Office (CSO) titled Further Training of Employees in Enterprises in the Czech Republic in 2010 showed, that even during a financial crisis, about three-quarters of companies were trying to find ways of not restricting their employees in their continuing education and training. Mostly businesses with over 500 employees invested in the training [13], [17]

In the Czech Republic as well as in the European Union there are programs encouraging companies to educate employees. For example one of them is "Educate yourself for growth". 850 million Czech crowns is available for this program from the European Social Fund and the Czech state budget, intended for companies hiring new employees or current employees teaching the new employees. In the case of obtaining a grant, a company is reimbursed for the course as well as for the wage of the employee. With these programs, in times of crisis the companies may educate their key employees as well as others in a limited way. The issue of the program is the high administrative burden, which means high costs for preparing the grant application in smaller companies without the sufficient knowledge of staff in the human resources department, if there is any. [4]

However, despite this support, in smaller and medium-sized companies spending on staff training is reducing. The economic crisis is taking longer than expected and companies can no longer afford staff training as before. There had to be a reduction of education, and now training mainly involve workers who are needed for a company. The world is constantly evolving and changing, more new technology is coming on the market, including the field of education. One possibility is the introduction of e-learning in corporate training.

Kopecky [16] defines e-learning in a broader sense as the application of new multimedia technologies and Internet in education to improve its quality by enhancing the access to resources, services, information exchange and co-operation, in the narrower sense e-learning is seen especially as education, which is supported by modern technologies and is implemented through computer networks - especially Internet and Intranet. E-learning cannot replace all forms of learning, but it can significantly streamline the education system. The original reason for organizations to implement e-learning was mainly to reduce costs, but today it is clear that e-learning has many other advantages, such as time independence and individual learning, in the case of well-developed courses it also ensures high level of transmitted knowledge, standardized knowledge (everyone can get the same information, it is possibly to customize courses), student assessment with the same rules, the possibility in a short time to educate a large number of people, and many others.

The introduction part presents certain solutions for the implementation of the case study, the fundamental part of this paper is dedicated to the case study that addresses the issue of the effectiveness of e-learning compared to traditional teaching. A pedagogical experiment was chosen as the main research method to compare the effectiveness. Based on the results, the conclusions are further discussed and the research directions are proposed.

\section{E-learning and Its Effectiveness}

In connection with the rapid progress in information technology over the past two decades, online education dramatically increases and e-learning thus affected many areas, including management training. There are many e-learning programs and e-learning incorporated to the conventional teaching methods. This trend was inevitable, since the popularity of online communication and social networking has been a phenomenon in recent years.

In addition, Schweizer [27] says that e-learning is replacing face-to-face classroom instruction in a growing number of businesses, but what is the prospect for the continued proliferation of e-learning in business? On the one hand, the quality of instruction, the costeffectiveness of new technology, a supportive e-learning educational culture, an expansion of the Internet, an increase in online courses, shorter business cycles, mergers, and increasing competition encourage business use of e-learning. On the other hand, employee reticence in using learning technologies, insufficient corporate investment, a lack of business- 
relevant university courses, narrow bandwidth, and the Internet access issues are constricting the business use of these technologies.

Nevertheless, the beneficial effects of learners interacting in online programmes have been widely reported [7]. Indeed, online discussion is argued to promote studentcentred learning. It is therefore reasonable to suggest that the benefits of online discussion should translate into improved student performance. The current study examined the frequency of online interaction of 122 undergraduates and compared this with their grades at the end of the year. The findings revealed that greater online interaction did not lead to a significantly higher performance for students achieving passing grades; however, students who failed in their courses tended to interact less frequently [7].

Furthermore, Ladyshewsky [18] explains: "The use of information technology in higher education has increased significantly over the years. There is a paucity of controlled research which examines differences in electronic learning (EL) and face to face (F2F) learning. This study examined student $(n=1401)$ performance (final grade) in nine units offered in both F2F and EL mode over the course of two years. The effect of age and gender was also considered. Students, on average, did better in the EL mode although at the individual unit level there were minimal if any significant differences. Age and gender did not appear to moderate performance in any way except for those students under 33 who did better, on average, in the EL mode."

Several studies have been also conducted in relation to dropouts from on-campus and distance education courses [19]. However, no clear definition of dropout from academic courses was provided. Consequently, this study proposes a clear and precise definition of dropout from academic courses in the context of e-learning courses. Additionally, it is documented in literature [19] that students attending e-learning courses dropout at substantially higher rates than their counterparts in oncampus courses. Little attention has been given to the key factors associated with such substantial difference. This study explores two main constructs: (1) academic locus of control; and, (2) students' satisfaction with e-learning. Results show that students' satisfaction with e-learning is a key indicator in students' decision to dropout from e-learning courses. Moreover, dropout students (non-completers) reported to have significantly lower satisfaction with e-learning than students who successfully completed (completers or persistent students) the same e-learning courses. Additionally, results of this study show that the academic locus of control appears to have no impact on students' decision to drop from e-learning courses [19].

Of course, there is also a significant group of opponents who argue that the evidence for e-learning is inconclusive [26].

The results of most studies suggest that there is no statistically significant difference in the results of students studying in the form of e-learning and traditional way of learning. [1], [5], [11], [15], [21], [32], [33]. The comments across the thematic areas (information technology, management, marketing, languages, etc.) uneven, but comprehensive overview of the e-learning research concluded that the results of students studying in the form of e-learning or traditional learning are not significantly different, there is no statistically significant difference [24].

This conclusion is a base for further construction and presentation of the case study which shall test the hypothesis $\mathrm{H}$ : Students achieve a comparable level of proficiency in ICT of the supported learning in comparison with face-to-face manner in basic management skills.

\section{Use Case - A Comparison of the Effectiveness of E-learning and Traditional Teaching (Pedagogical Experiment Results)}

As stated in the previous chapter, companies try to keep corporate training in hard and soft skills; education in management should be part of education in every organization. Selection of an appropriate form of education should be based on the $\mathrm{BI}$ system and should combine the two basic breakdowns of the educational process: regulated - unregulated and working - non-working, thus we can get six possible forms of education [2]:

1. Regulated training of work performance in a workplace (the so-called informal education).

2. Regulated training outside of work performance in a workplace (the so-called formal education). 
3. Regulated training off the site of the employer (the so-called institutionalized education).

4. Unregulated training of work performance in a workplace (the so-called informal education).

5. Unregulated training outside of work performance in a workplace (the so-called interpersonal education).

6. Unregulated training off the site of the employer (the so-called lifelong selfeducation).

E-learning (m-learning) [12], [23], [25], [21] can be used for all six possible forms of education. The following section is therefore devoted to comparison of the effectiveness of e-learning and traditional teaching in the acquisition of basic management skills. This pedagogical experiment was carried out under the GACR 406/09/0669 project called "Evaluation of the benefits of modern technology in the process of formation and development of competencies of university students", which inter alia aim was to evaluate the effectiveness of e-learning.

\subsection{The Object of the Pedagogical Experiment}

The research objective was to verify whether the appropriate use of e-learning leads to a comparable performance of students in the area of cognitive learning.

The object of the research can be characterized as follows:

1. Educational process in course of the Principles of Management.

2. University students (Faculty of Informatics and Management, University of Hradec Kralove) participating in the course of the Principles of Management.

The research subject is students' performance achieved in the experimental group in the cognitive area and its comparison with the performance of students achieved by traditional full-time education in course of the Principles of Management.

At first glance it may seem that students and employees are two groups which are difficult to compare. For the purposes of our experiment, i.e. verifying comparability of the effectiveness of e-learning and traditional teaching, the difference is irrelevant. Corporate education also involve various employees (differences in age, education, experience, etc.) [10]. The main hypothesis is:

$\mathrm{H}$ : Students reach higher level of knowledge in the ICT-supported instruction in comparison to the face-to-face way.

\subsection{The Research Methodology and Organization}

The research used the following methods [9]:

- experiment - the main method,

- educational tests - the hypothesis verification,

- interview (to a limited extent),

- observation (to a limited extent),

- statistical methods of processing the results of the research.

A suitable method for comparing the effectiveness of two different systems of teaching is a pedagogical experiment.

One of the important conditions in the organization of the experiment is that the experimental and control group are the most equal. The experimental group is a group of subjects, in which the experimental change was applied, in our case it is a group of students in which they use e-learning for education. The control group is a group of subjects, in which there is no experimental change, in our case the students who use traditional methods of education (full-time education).

The experimental method uses a special term to describe the experimental change - the independent variable. In our educational research the independent variable is the use of e-learning. The dependent variable in the experiment was the performance of students memory, understanding and application of new knowledge.

The research used an experimental plan using pre-test and post-test.

When evaluating the effectiveness of education, didactic tests are used that will play an important role here. Entrance test (pre-test) will verify that the initial knowledge is same in both groups. Output test No. 1 (post-test1) will measure, whether the experimental change e-learning - influenced students' knowledge compared to traditional teaching. Output test No. 2 (post-test2) will test the permanence of knowledge. All educational tests that have 
been used in the research, were designated for the measurement of educational process outcomes in cognitive learning. Creation of the tasks in didactic test was based on clearly defined objectives and curriculum analysis.

Individual tasks were defined based on the taxonomy of educational objectives of Tollingerova [33] - the first three categories were used:

1. Tasks requiring a commemorative reproduction of knowledge.

2. Tasks requiring simple mental skills with knowledge.

3. Tasks requiring complex mental skills with knowledge.

Number of tasks in the thematic units was set in proportion to the number of hours that are devoted to the interpretation of individual topics.

The pre-test contained 8 tasks, the posttest contained 12 . To determine the reliability of tests they are not high numbers, but the reliability value of the pre-test reached 0.6008 ; the post-test reliability value was 0.672 . Test reliability was set by the Kuder-Richardson formula.

\subsection{Organization of the Study}

In the case of "traditional" teaching the students had the opportunity to attend lectures and seminars. While attendance at lectures was not mandatory, attendance at seminars was recorded and was one of the conditions for gaining credit. The lectures presented successively different thematic units. Verbal presentation of topics was supplemented with PowerPoint presentations. Within seminars the students had to solve various sub-tasks and case studies, and had to prepare a seminar paper (SWOT analysis of the selected product, company, service, etc.) To obtain the credit they also had to write a midterm test (minimum 7 points out of 14).

The "experimental" teaching used the socalled e-subject of the POM1 within the virtual study environment of OLIVA. The basis of the virtual study environment consists of LMS (Learning Management System), WebCT, in which each e-subjects are operated. Students included in the control group did not have access to the e-subject of the POM1 during the semester or prior to the test. For students of the experimental group there was no scheduled lecture or seminar, instead that they had study supports available of the e-subject of the
POM1. All communication with a teacher took place only in the WebCT environment. Students had to solve sub-tasks and case studies independently, the selected tasks were mandatory, so the students had to develop and submit them to the teacher. The course completion was linked to the development and delivery of 8 mandatory sub-tasks and passing the final test.

\subsection{Selection of the Research Sample}

In usual school practice, totally random selection for experimental research is impossible.

Available selection was used to select the research sample, so of course it is not possible to generalize the results and state that this applies in every area, with any participant, etc.

The research sample consisted of university students (University of Hradec Kralove, Faculty of Informatics and Management), who participated in the Principles of Management course in the academic year 2009/10 and 2010/2011.

The experimental and control group was created with random selection. The number of participants in the experiment is shown in the following table (Table 1). In some cases, the number is lower in the post-test than in the pretest, because not all participants completed the course.

\begin{tabular}{l|c|c|c|c} 
Tab. 1: & $\begin{array}{l}\text { The number of participants in } \\
\text { educational experiment }\end{array}$ \\
& \multicolumn{2}{|c}{ Pre-test } & \multicolumn{2}{c}{ Post-test } \\
\cline { 2 - 5 } & E & C & E & C \\
\hline Year 1 & 35 & 37 & 32 & 34 \\
\hline Year 2 & 44 & 39 & 44 & 39 \\
\hline Total & 79 & 76 & 76 & 73 \\
\hline \multicolumn{5}{|c|}{ Source: custom processing. Legend: }
\end{tabular}

The experimental group $-E$, the Control group $-C$.

\subsection{Analysis of the Research Results}

Input knowledge test - pre-test - was created in order to determine the input level of knowledge before the experimental exposure. Due to the fact that the course Principles of Management course is not attached to another course, the test included questions concerning 
the substance of the Principles of Management. The pre-test was necessary to verify that the input knowledge of students is equal, otherwise it wouldn't have much point to implement the pedagogical experiment.

At the end of the experiment the participants passed the test of output knowledge - post-test - it was created in order to determine the output level of knowledge after experimental exposure. After three months, the post-test was repeated to confirm the permanence of knowledge. Using the statistical program of NCSS2007, by Student t-test and non-parametric MannWhitney's test (due to not completely clear normal distribution) analysis of variance at the significance level of 0.05 was conducted for checking the statistical equivalence of the sample in indicators of the pre-test, post-test1 and post-test 2 results. The results are shown in the following two tables and charts (Tables 2 and 3 , Fig. 1 and 2 ).

The objective of this test was to verify the following hypothesis:

"There is no statistically significant difference in test scores in experimental and control groups."

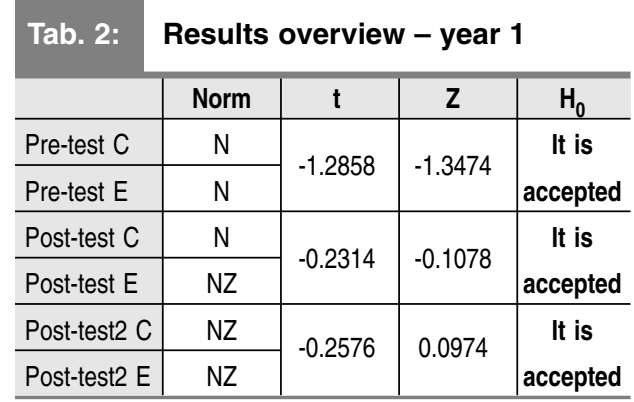

Source: custom processing. Legend: The experimental group - E, the Control group - C, Norm (test of normality): $N$ (normal distribution), NZ (cannot be rejected), Z (rejected), t (t-test) and Z (Z-test)

\section{Tab. 3: Results overview - year 2}

\begin{tabular}{|c|c|c|c|c|}
\hline & Norm & $t$ & Z & $\mathrm{H}_{0}$ \\
\hline Pre-test C & $\mathrm{N}$ & \multirow{2}{*}{0.6438} & \multirow{2}{*}{-0.4969} & \multirow{2}{*}{$\begin{array}{c}\text { It is } \\
\text { accepted }\end{array}$} \\
\hline Pre-test $\mathrm{E}$ & $\mathrm{N}$ & & & \\
\hline Post-test C & NZ & \multirow{2}{*}{0.2722} & \multirow{2}{*}{-0.2303} & \multirow{2}{*}{$\begin{array}{c}\text { It is } \\
\text { accepted }\end{array}$} \\
\hline Post-test E & $\mathrm{N}$ & & & \\
\hline Post-test2 C & $\mathrm{N}$ & \multirow{2}{*}{0.0640} & \multirow{2}{*}{0.0328} & \multirow{2}{*}{$\begin{array}{c}\text { It is } \\
\text { accepted }\end{array}$} \\
\hline Post-test2 E & $\mathrm{N}$ & & & \\
\hline
\end{tabular}

Source: custom processing. Legend: The experimental group - E, the Control group - C, Norm (test of normality): $\mathrm{N}$ (normal distribution), NZ (cannot be rejected), Z (rejected), t (t-test) and Z (Z-test)

\section{Fig. 1: Performance of students in the pre-test and post-test1 - year 1}
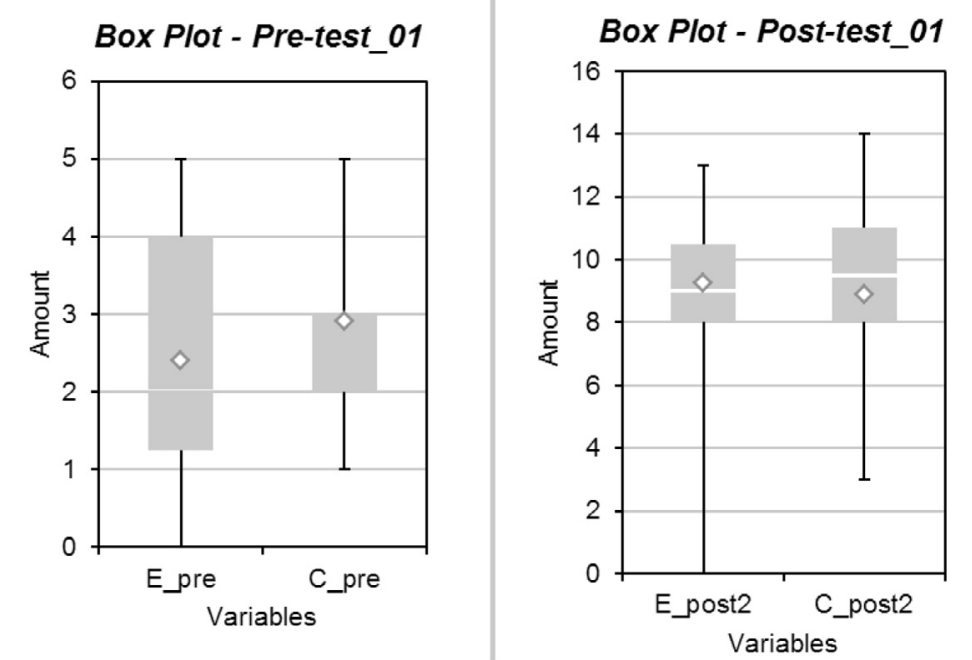

Source: custom processing 


\section{Fig. 2: Performance of students in the pre-test and post-test1 - year 2}

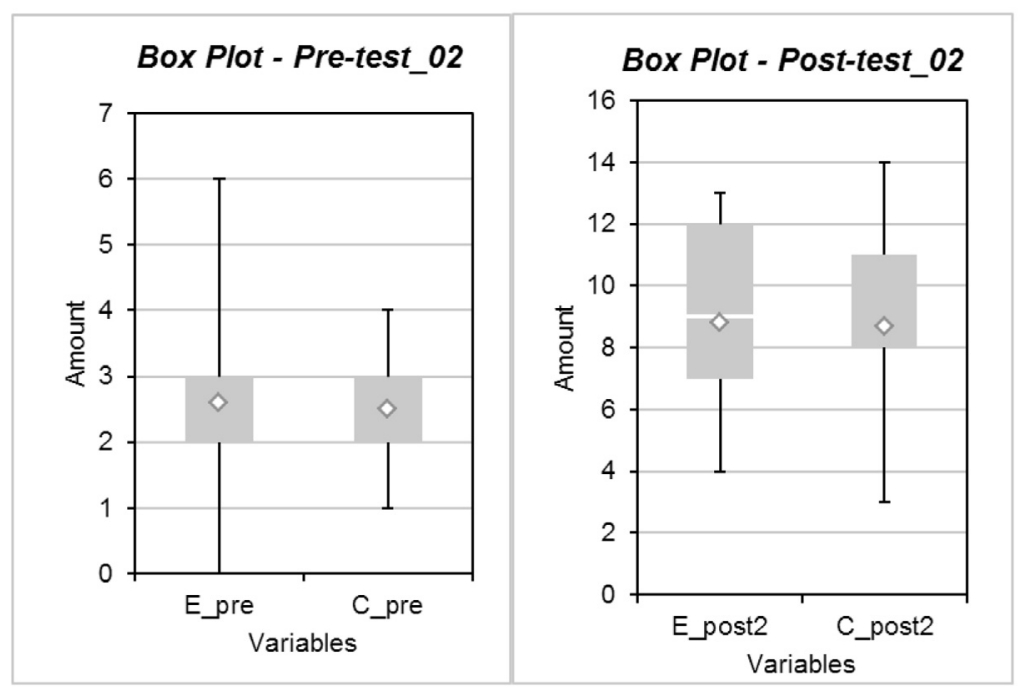

Source: custom processing. Legend: The first chart shows the pre-test (experimental versus control group), the second chart shows the post-test (experimental versus control group).

Table critical value of the test criteria is Tcrit $=1.9866$.

All calculated values of the test criteria Tcalcul were lower than the critical value.

$$
\left(\ldots \ldots \ldots \ldots \ldots . . . .=T_{\text {vypoč }} \leq T_{\text {krit }}=1,9866\right) .
$$

The null hypothesis is therefore accepted, in post-test1 and post-test2 there was no statistically significant difference between the performance of students enrolled in the control and experimental groups.

The validity of the null hypothesis is confirmed by the non-parametric Mann- Whitney's test.

This result concludes that the main hypothesis Students reach higher level of knowledge in the ICT-supported instruction in comparison to the face-to-face way was rejected.

The hypothesis of "The students in the experimental group will achieve a comparable performance in cognitive learning at the end of the experimental teaching as the students taught by traditional full-time teaching" is true.

\section{Summary of the Results}

One of the most important aspects of e-learning introduction into the company training system is its efficiency. Exploitation of e-learning is not possible in all cases - it must be considered carefully if the given task is to be trained by e-learning.

Based on the conducted experiment, we can state that training in basic managerial skills with the help of e-learning is same efficient as traditional education methods. These findings are important when deciding about the implementation of this tool in company training. Similar educational experiment was conducted in other areas such as database systems or professional English and Šimonová [30], [31], [31] confirms these results.

However, all competencies are not obtainable when using this method - when implementing e-learning, it is important to assess all these cases individually.

From these results it is clear that education through E-learning is comparable to that of traditional teaching. It does not replace all forms of learning, but it can significantly streamline the education system. The original reason for organizations to implement e-learning was mainly cost reduction, but today it is clear that e-learning has many other benefits. Implementation of e-learning has many positive facts such as [8], [9], [22]: 
- time independence and individual study,

- possible reduction of costs compared to traditional education,

- in the case of well-made courses, it ensures a high level of transmitted knowledge,

- standardized knowledge (everyone receives the same information),

- assessment of students according to the same rules,

- possibility to educate large number of people in a brief moment,

- courses can be made in an interesting and entertaining way that will appeal to more students, etc.

On the other hand, it is obviously necessary to mention the possible negatives and barriers to the introduction of this form of learning, such as [22]:

- not appropriate for anybody (requires computer literacy),

- impersonal education,

- problems with the motivation of participants,

- knowledge is served in one way, which may be unsuitable for some people,

- it is necessary to have the necessary technical equipment (ICT technology) and others.

\section{Research Limitations and Areas for Further Research}

Based on the experiment, we can conclude that training in basic management skills through e-learning in the context of the studied sample is as equally effective as traditional training. This finding is important when deciding on the implementation of this tool in corporate education in this area.

At first glance it may seem that students and employees are two groups which are difficult to compare. For the purposes of our experiment, i.e. verifying comparability of the effectiveness of e-learning and traditional teaching, the difference is irrelevant. Corporate education also involve various employees (differences in age, education, experience, etc.)

In any case it can not be generally stated that e-learning is always and under all circumstances the same or equally effective as traditional teaching. It is very specific and it is always necessary to consider the circumstances completely individually. What we want to teach is important, what skills and knowledge the participants shall obtain, who the participants are, etc.
The issue certainly has potential for further exploration; there are many areas for further researches. One of the directions is a deeper examination of the same facts (comparing the effectiveness of e-learning and traditional training) under different conditions, such as in corporate training and further analyze the factors that are critical when considering the introduction of e-learning. Another area is the use of ICT technologies even further, such as the use of social media.

\section{Conclusion}

Classic school education in lifelong learning terminology is referred to as formal education, which can be characterized by longer duration and higher requirements for participants involvement. Informal education is different. Organized and institutionalized educational activities are used the form of courses, training courses, private lessons, workshops or seminars. In 2011, in the Czech Republic nearly a third (32\%) of people between 18 and 69 years participated in at least one such activity. [6]

Employers usually support formal and informal learning, participation of an employer may take the form of direct financing or releasing employees within their working hours. Within the information system it is possible to monitor and gather information on education processes and then use them for not only assessing the effectiveness of education, but also to identify the needs of further training, selection of the form of education and to plan the whole process. [3]

The decision-making process regarding the implementation of e-learning into corporate education system is a very complex procedure that is divided into several separate decision issues, which are very important, when in fact a breach of one of these conditions may result in a negative opinion towards to introduction of e-learning.

Before incorporating e-learning in the process of education it is necessary to consider in particular these aspects [28], [29]:

- content of the course - the appropriateness of education of the given matter through e-learning (efficiency);

- assumptions of the educational institution ICT facilities, staffing;

- assumptions of students - ICT literacy, access to ICT;

- and finally, the ECONOMIC ASPECTS. 
Such information can also be obtained on the processes of learning and use them to assess the effectiveness of education as well as to identify the needs for further training, selecting the forms of education and to plan the whole process of education. In the process of training we obtain a lot of data and reports, mostly in e-learning. With the help of Business Intelligence tools the process of education can be even more efficient. It is possible to analyze, measure, assess and evaluate the performance of the trained participants and operationally modify the training materials according the current needs. As a consequence, we can observe and analyze the interaction of the trainees with the e-learning environment. They can also help with the training content assessment and its efficiency in the educational process.

The future of corporate training can be expected in the technology-supported network systems, in the case of those educational programs for which there is high social demand. However, among the indisputable advantages they are also some drawbacks, which must not be neglected in both the creators of e-learning products and consumers.

This paper was supported by GACR 406/09/0669 "Evaluation of the benefits of modern technology in the process of formation and development of competencies of university students" and Grant Agency of Excellence, University of Hradec Kralove, Faculty of Informatics and Management, No. 2013.

\section{References}

[1] ALLEN, M., BOURHIS, J., BURRELL, N., MABRY, E. Comparing student satisfaction with distance education to traditional classrooms in higher education: A meta-analysis. American Journal of Distance Education. 2002, Vol. 16, Iss. 2, pp. 83-97. ISSN 0892-3647.

[2] ARMSTRONG, M. Řízení lidských zdrojů. Praha: Grada Publishing, 2007. ISBN 80-247-1407-8.

[3] BARTÁK, J. Jak vzdělávat dospělé. Praha: Nakladatelství Alfa, 2008. ISBN 978-80-87197-12-7.

[4] Benchmarking. Firmy $i v$ době krize investují do svých zaměstnanců [online]. Czech Business, 2012. [cit. 2012-05-05]. Available from: http://www.czech-business.com/tiskova-zprava20120214-firmy-i-v-dobe-krize-investuji-do-vzdelavani-svych-zamestnancu.php.

[5] BERNARD, R.M. et al. How does distance education compare with classroom instruction? A meta-analysis of the empirical literature. Review of Educational Research. 2004, Vol. 74, Iss. 3, pp. 379-439. ISSN 0034-6543.

[6] BÖHM, D. V ČR se vzdělává polovina zaměstnanců. Statistika a my. 2013, roč. 3, č. 6, s. 21. ISSN 1804-7149.

[7] DAVIES, J., GRAFF, M. Performance in e-learning: online participation and student grades. British Journal of Educational Technology [online]. 2005, Vol. 36, Iss. 4 [cit. 2013-12-11], pp. 657-663. Available from: http://onlinelibrary.wiley.com/doi/ 10.1111/j.1467-8535.2005.00542.x/full. ISSN 1467-8535.

[8] FRYDRYCHOVÁ KLÍMOVÁ, B., POULOVÁ, P. Tutor as an Important E-learning Support. Procedia Computer Science. 2011, Vol. 3, pp. 1485-1489. ISSN 1877-0509.

[9] FRYDRYCHOVÁ KLÍMOVÁ, B. Making Academic Writing Real with ICT. Procedia Computer Science. 2011, Vol. 3, pp.133-137. ISSN 1877-0509. [10] GAVORA, P. Úvod do pedagogického výzkumu. Brno: Padio, 2000. ISBN 978-80-3715-185-0.

[11] HANSEN, D.E. Knowledge transfer in on-line learning environments. Journal of Marketing Education. 2008, Vol. 30, No. 2, pp. 93-105. ISSN 0273-4753.

[12] Hewlett-Packard Development Company. L.P. [online]. [cit. 2013-12-11]. Available from: http://www.hp.cz/e-learning/elearning.php.

[13] HR News. Projekt „Vzdělávejte se pro růst!“ pokračuje $\mathrm{v}$ regionech. HR News [online] IVITERA, 2011 [cit. 2012-05-14]. Available from: http://www.hrnews.cz/lidske-zdroje/rozvoj-a-vzdelavani-id-148692/ projekt-vzdelavejte-se-pro-rustpokracuje-v-regionech-id-1464107.

[14] HRONÍK, F. Rozvoj a vzdělávání pracovníků. Praha: Grada Publishing, 2006. ISBN 978-80-2471457-8.

[15] IVANCEVICH, J.M., GILBERT, J.A., KONOPASKE, R. Studying and facilitating dialogue in select on-line management courses. Journal of Management Education. 2009, Vol. 33, Iss. 2, pp. 196-218. ISSN 1052-5629.

[16] KOPECKÝ, K. E-learning (nejen) pro pedagogy. Olomouc: HANEX, 2006. ISBN 80-85783-50-9.

[17] KOTÝNEK, J. Krize nekrize, zaměstnanci dál chodili na kurzy. Statistika a my. 2013, roč. 3, č. 6 , s. 24. ISSN 1804-7149.

[18] LADYSHEWSKY, R.K. E-learning compared with face to face: Differences in the academic achievement of postgraduate business students. Australasian Journal of Educational Technology 
[online]. 2004, Vol. 20, Iss. 3 [cit. 2013-12-11], pp. 316-336. Available from: http://www.ascilite.org. au/ajet/ajet20/ladyshewsky.html. ISSN 1449-5554. [19] LEVY, Y. Comparing dropouts and persistence in e-learning courses. Computers \& Education. 2007, Vol. 48, Iss. 2, pp. 185-204. ISSN 0360-1315.

[20] MAREŠOVÁ, P. Výzkum uplatnění znalostního managementu $v$ českých podnicích. $E+M$ Ekonomie a Management. 2010, Vol. 13, Iss. 1, pp. 131-144. ISSN 1212-3609.

[21] POULOVÁ, P., ŠIMONOVÁ, I. The Traditional versus ICT-supported instruction within the Tertiary Education: Comparative Study. In i-Society 2011: international conference: proceedings. London, 2011. ISBN 978-0-9564263-8-3.

[22] POULOVÁ, P., SOKOLOVÁ, M., ŠIMONOVÁ, I. Předpoklady zavedení e-learningu do vysokoškolského vzdělávání a hodnocení jeho přínosu v procesu formování a rozvoje kompetencí studentů. AULA. 2010, Vol. 18, Iss. 3, pp. 20-27. ISSN 1210-6658.

[23] RASHID, M.A. et al. Strategic e-Commerce Model Driven-Architecture for e-Learning: TQM and e-ERP Perspective. In KOCAOGLU, D.F., ANDERSON, T.R., DAIM, T.U. (Eds.). 2011 Proceedings of Picmet 11: Technology Management in the Energy-Smart World (PICMET 2011). Portland (OR): IEEE, 2011. pp. 1577-1590. ISBN 978-1-890843-23-6.

[24] REDPATH, L. Confronting the Bias Against On-Line Learning in Management Education. Academy of Management Learning and Education. 2012, Vol. 11, No. 1, pp. 125-140. ISSN 1537-260X. [25] ROSMAN, P. M-learning - a Paradigm of New Forms in Education. E+M Ekonomie a Management. 2008, Vol. 11, Iss. 1, pp. 119-125. ISSN 1212-3609.

[26] SHACHAR, M. Meta-analysis: The preferred method of choice for the assessment of distance learning quality factors. International Review of Research in Open and Distance Learning. 2008, Vol. 9, No. 3, 15 p. ISSN 1492-3831.

[27] SCHWEIZER, H. E-Learning in Business. Journal of Management Education [online]. 2004, Vol. 28, Iss. 6 [cit. 2013-12-11], pp. 674-692. Available commercially from: http://jme.sagepub.com/ content/28/6/674.full.pdf+html. ISSN 1552-6658.
[28] SOKOLOVÁ, M. Analysis of the effectiveness of teaching with the support of eLearning in the course of Principles of Management I - performance analysis. Procedia - Social and Behavioral Science. 2011, Vol. 28, pp. 174-178. ISSN 1877-0428. [29] SOKOLOVÁ, M. Comparison of the effectiveness of teaching with the support of eLearning to the effectiveness of traditionalhigher education in the course of Principles of Management - comparison of the growth dynamics in the performances. Procedia - Social and Behavioral Science. 2011, Vol. 28, pp. 179-183. ISBN 1877-0428.

[30] ŠIMONOVÁ, I., POULOVÁ, P., JANEČKA, P. Didactic Approaches to ICT-Enhanced Teaching and Learning. In ICEEE 2012: proceedings of the international conference on e-learning and e-technologies in education. Lodž: IEEE, 2012. pp. 37-42. ISSN 978-1-4673-1677-4.

[31] ŠIMONOVÁ, I., POULOVÁ, P., SOKOLOVÁ, $\mathrm{M}$. Klíčové kompetence a jejich reflexe $v$ terciárním e-vzdělávání: e-learning $v$ odborné angličtině $v$ komparaci $s$ dalšími oblastmi manažerského vzdělávání. 1. vyd. Hradec Králové: M. Vognar, 2011. 143 p. ISBN 978-80-86771-46-5.

[32] ŠıMONOVÁ, I. et al. On Contribution of Modern Technologies Towards Developing Key Competences. 1st ed. Hradec Králové: M. Vognar, 2009. 192 p. ISBN 978-80-86771-38-0.

[33] TOLLINGEROVÁ, D. Úvod do teorie a praxe programované výuky a výcviku. Príloha časopisu. Odborná výchova. 1970-1971, roč. 21, č. 5, s. 143-146. [34] WILLIAMS, S.L. The Effectiveness of Distance Education in Allied Health Science Programs: A Meta-Analysis of Outcomes. American Journal of Distance Education. 2006, Vol. 20, Iss. 3, pp. 127-141. ISSN 0892-3647.

doc. Ing. Hana Mohelská, Ph.D. University of Hradec Králové

Faculty of Informatics and Management Department of Management hana.mohelska@uhk.cz

Ing. Marcela Sokolová, Ph.D. University of Hradec Králové Faculty of Informatics and Management Department of Management marcela.sokolova@uhk.cz 


\section{Abstract}

\section{EFFECTIVENESS OF USING E-LEARNING FOR BUSINESS DISCIPLINES: THE CASE OF INTRODUCTORY MANAGEMENT COURSE \\ Hana Mohelská, Marcela Sokolová}

Education and development of employees in the traditional sense focus on the formation of working abilities of a person and that part of their personality, through which they create values in order to improve the work performance of individuals, to fulfil their individual goals within their working career and improve the performance of an organization as a whole. The purpose of education is to promote competitiveness and a greater flexibility of workers in a rapidly changing environment. Organizations must therefore use all available methods of education appropriately combined, and to set the whole process of education to be not only effective, but also financially acceptable. The economic crisis is taking longer than expected and companies can no longer afford staff training as before. One possibility is the introduction of e-learning in corporate training.

The paper describes the various forms of education and based on the results of custom research (experiment) it compares the effectiveness of e-learning and traditional learning.

Based on the conducted experiment, we can state that training in basic managerial skills with the help of e-learning is same efficient as traditional education methods.

On the basis of the facts it certainly cannot be clearly stated that each organization (educational institution, business) shall introduce e-learning into the education system of their employees. It is necessary to access each organization individually. There are mentioned criteria and tools that can help you decide. There are also other possible research directions discussed.

Key Words: E-learning, corporate education, experiment.

JEL Classification: 121, I25, L20.

DOI: 10.15240/tul/001/2014-1-007 